\title{
The influence of microclimate on the calves' bodies in the bioclimatic conditions of the Caspian lowlands in Dagestan
}

\author{
Tatyana Mayorova ${ }^{1, *}$, Jabrail Musiev ${ }^{1}$, Shakhrudin Gunashev ${ }^{1}$, Raisa Abduragimova ${ }^{1}$, and \\ Yusup Bariev ${ }^{2}$ \\ ${ }^{1}$ FSBEI HPE Dagestan SAU named after M.M. Dzhambulatov, Makhachkala, Russia, \\ ${ }^{2}$ FSBEI of HE Dagestan SAU Agrarian and Economic Technical College' Makhachkala, Russia
}

\begin{abstract}
The aim of our research was to study the microclimate's influence on some clinical and physiological parameters of calves in the conditions of livestock complexes of the Republic of Dagestan. Research methods: veterinary, zootechnical, logical, systemic. The results of the study of calf pen microclimate parameters showed the range of fluctuations: temperature $6,5-22,5{ }^{0} \mathrm{C}$, humidity $74.2-98.1 \%$, air velocity $0.25-0.40 \mathrm{~m} / \mathrm{s}$, carbon dioxide concentration $0.4-0.2 \%$ and ammonia $2-6 \mathrm{mg} / \mathrm{m}^{3}$. The study results of the clinical and physiological calves' state showed changes in body temperature from 38.0 to $39.3{ }^{\circ} \mathrm{C}$, pulse rate from 65 to 71 beats per minute, respiratory frequency movements from 22 to 26 per minute. The results of hematological studies has shown that the studied indicators had a range of fluctuations: hemoglobin 8.6 - $9.4 \mathrm{~g} \%$, erythrocytes 7.1-7,9, leukocytes 7.28.9 th. $/ \mathrm{mm}^{3}$. Conclusions. The study results of the calf pen microclimate showed that it complied with zoohygienic norms. The relative humidity and air velocity indicators exceeded the permissible zoohygienic standards. Indicators of calves' physiological condition corresponded to the norms of a healthy animal. Hematological and biochemical blood indicators of calves were within the physiological norm.
\end{abstract}

\section{Introduction}

The study of climate and microclimate influence on the body and their importance in increasing productivity, resistance and in the etiology of animal diseases is a topical issue and is currently being studied with consideration of modern methods to optimize the animal breeding technology. Modern scientists note that the factors that cause high productivity of animals include the air environment condition of the premises. It is an irritant that causes various reactions in them, as well as adaptive elements [1]. While performing the work, many researchers eventually concluded that natural resistance and immunobiological reactivity vary depending on the keeping conditions, time of year and productivity level.

The climate of Dagestan is characterized by hot dry summers with strong winds and moderate dry winters with noted presence of altitudinal zonation. The annual average

\footnotetext{
* Corresponding author: free_77@mail.ru
} 
temperature is $+11.8{ }^{\circ} \mathrm{C}$. Winter is mild. The temperature of January is $0,4^{\circ} \mathrm{C}$. Minimum temperatures in winter rarely fall below $-20^{\circ} \mathrm{C}$, but below $-9^{\circ} \mathrm{C}$ - almost every year. At the same time, the average maximum of January is $+2.4^{\circ} \mathrm{C}$, and the average of absolute maximum is $+10^{\circ} \mathrm{C}$. The average number of days with snow cover is 25 . The widespread distribution of temperature inversions and associated mists, low cloudiness and drizzling precipitation is characteristic. Winter winds are mainly WNW and ESE directions wind speed from 2.8 to 33 $\mathrm{m} / \mathrm{s}$. [2]. When building livestock houses in the lowland zone of Dagestan, it is necessary to consider the features of the climate, high humidity of atmospheric air, its periodical dustiness and strong winds. The maintenance of animals in premises meeting the zoohygienic requirements allows to significantly reduce mortality and increase productivity [3].

It is necessary to develop zoohygienic norms of winter livestock keeping by climatic zones as research institutions give little attention to the study of regional zoohygiene issues. This is due to that the existing standards of winter animals' keeping for various types of farm animals are still insufficiently substantiated in the zoning aspect. The conditions of the stabling period depend on a number of specific features of the buildings and the operating conditions of the premises. An important influence on the animals' keeping conditions in the premises is by cubage, floor arrangement, ventilation, sewerage, illumination, as well as maintenance of neatness in the premises. To ensure the proper condition of the air environment in their design and construction, it is necessary to precisely comply with the established standards and technical requirements [4].

In livestock premises built in the past, the microclimate does not meet zoohygienic requirements [5]. In Dagestan, calves are kept in unheated rooms, so microclimate indicators depend significantly on climatic conditions. Calves' keeping in a room with high humidity and at low temperatures affects the homeostasis of the body, reflecting on hematological and biochemical indicators. In most livestock premises, air exchange is regulated by means of dampers increasing and decreasing the flow of fresh air; when the temperature of the outside air decreases, the dampers are closed and air exchange is minimized, which leads to an increase in the carbon dioxide content, provokes increased breathing, irritation of the mucous membranes; calves become sluggish, they have decreased appetite and lose weight. At high values of carbon dioxide concentration, asphyxia and death occur. With an increase in ammonia content in the rooms' air, calves' homeostasis is disturbed, which is manifested by convulsions, comatose conditions, hypertension, breathing paralysis and death [6]. Allahverdie I.I. (1979) pointed out that the creation of a microclimate meeting zoohygienic requirement is of major importance for healthy young cattle breeding, especially during the first period of life along with full-fledged feed.

The generalization of the literary data show that the unsatisfactory microclimate of calf pan has a noticeable effect on the health, resistance, and average daily gains of young cattle. With an unsatisfactory microclimate, calves show delayed growth and development and there are diseases of bronchial pneumonia and dyspepsia with a significant 5 to $30 \%$ of mortality among them. The cost of feed can be much higher than planned: for feed units - by $12.6 \%$ and digested protein - by $13 \%$. Adverse microclimate negatively affects the overall resistance of the body and susceptibility of calves to socially significant infectious diseases (tuberculosis, brucellosis, leukosis). Therefore, for animals to maintain health and increase productivity, it is necessary to create conditions that meet the zoohygienic requirements [7].

Based on the above, the aim of our research was to study the microclimate's influence on some clinical and physiological parameters of calves in the conditions of livestock complexes in the Republic of Dagestan. 


\section{Materials and Methods}

Research was carried out in livestock farms located on the Caspian lowlands of the Republic of Dagestan. Keeping conditions are close to natural: loose housing with free access to water and feed. Calves received a basic diet. Laboratory studies were performed at the Department of Epizootology of DagSAU. The study of the calves" physiological state was performed 3 times a month, once a day at the same time. Studies of microclimate parameters were carried out 3 times a day in different zones of the calf pan at a height of 80 and $150 \mathrm{~cm}$ from the floor. Generally accepted methods were used to study the microclimate. The gas composition of the air was studied using a universal gas analyzer (UG-2), carbon dioxide was determined by Subbotin-Nagorsky titrometric method, determination of the dust amount in the air was carried out by gravimetric (weight) method. Air humidity was determined by August's statistical psychrometer [8]. Physiological and biochemical indicators of the calves' body resistance condition were determined according to generally accepted veterinary methods, lysozyme activity - according to F. Matusevich.

Digital material of research results was processed by methods of mathematical statistics.

\section{Results of the study}

Studies of the temperature-humidity conditions of the calf pan showed that the average temperature in November was $17.5 \pm 0.25$ with a range of fluctuations from 14.5 to 19.5, and in December - $17,05 \pm 0.3516 .2$ to 17.5 , respectively. In December, the air temperature in the calf pan significantly decreased. The monthly average temperature for this month was $16.18 \pm 0.35$ with a fluctuation from 15.5 to 17.5 , and in February the temperature falls even lower. The average temperature for this month was $7.7 \pm 0.15$, the minimum amounted to 6.5 , and the maximum -9.0 degrees. In individual days it fell to $5^{\circ} \mathrm{C}$ and was approaching the minimum norm. The reason for the low air temperature was a cold snap of atmospheric and outdoor air $\left(0-2^{\circ}\right)$. In March, the average temperature rose significantly and amounted to $10.11 \pm 0.02$, ranging from 9.0 to $11.5^{\circ}$. In April it reached $17.8 \pm 0.43$ (15.5-19.5) and in May - 20.4 \pm 0.25 (17.7-22.0). Thus, the conducted studies show that the air temperature of the calf pan in February was lower than the permissible zoohygienic norm, and in November, December, January, March, April and May it corresponded to optimal norm. Relative humidity in the calf pan in November amounted to $91.0 \pm 2.4$ with fluctuations from 76.0 to 98\%; respectively, in December $91.0 \pm 2.7$ (78.7-96,3); January - 93.6 \pm 1.9 (89.9-98.7); February 86.5 \pm 4.5 (81.0-91.5); March 86.6 \pm 3.1 (86.0-91.0); April, 85.9 \pm 3.2 (74.0-91.8); May $84.7 \pm 2.5(77.2-92.7 \%)$. The data of the study show that the relative humidity over the period of the experiments significantly exceeds the permissible norm $(18 \%)$. The air velocity in the calf pan for all months of the study $(0,03-0.1 \mathrm{~m} / \mathrm{s})$ significantly exceeds the zoohygienic standard. In November it amounted to 0.32 , December -0.35 , January-0.4, February -0.37 , March-0.35, April -0.33, May - $0.33 \mathrm{~m} / \mathrm{sec}$. At the same time, the concentration of carbon dioxide, ammonia and hydrogen sulfide was determined in the calf pan air. We could not detect the hydrogen sulfide content in the air of the studied object. The concentration of carbon dioxide and ammonia for the entire period of the study did not exceed the permissible standard of GOST.

Studies of the physiological parameters of calves showed that their body temperature corresponded to the physiological norm with small fluctuation limits of $37.8 \pm 0.5-39.1 \pm$ 0.1 , respectively: pulse $-64.5 \pm 1,8-70.9 \pm 1.4$ and respiration $-22.6 \pm 1.0-20.1 \pm 2.2$. The results of hematological studies showed that the number of red blood cells is within the natural norm $(7,10 \pm 0.1-7.9 \pm 0,1)$, the number of leukocytes does not go beyond physiological norm $(7.2 \pm 0.29-9.8 \pm 0.2)$. The hemoglobin content corresponds to the indicators of a healthy animal $(8.4 \pm 0.17-9,41 \pm 0.39)$. The results of biochemical studies 
show that the content of protein fractions were within the physiological norm with small fluctuations that did not have a physiological change. Thus, the amount of total protein had a range of $6,50 \pm 0.21$ to $7,17 \pm 0.20$, albumin - from $2,43 \pm 0.03$ to $2,89 \pm 0.10$, alpha globulin had a minimum of $1,07 \pm 0.7$ and a maximum of $1.19 \pm 0.06(15.39 \pm 1.49-1.78 \pm 0.90 \%)$. Accordingly, beta globulins - (1.17 $\pm 0.007-1.36 \pm 0.05),(27.26 \pm 1,25-19.5 \pm 1.73 \%)$ and gamma globulins - 1,46 $\pm 0.20-1,34 \pm 0.11 \quad(13,83 \pm 2,31-26,19 \pm 1.19 \%)$. The protein coefficient was $0.58 \pm 0.03$ (smallest) and $0.70 \pm 0.1$ (greatest). As can be seen from the given data, the number of proteins and protein fractions in the calves' blood with small deviations with no physiological significance are within normal limits.

Natural body resistance is has a great importance to preserve health, increase productivity and in the prevention of farm animals' diseases. The animal organism's condition is influenced by factors of external environment, especially the parameters of the microclimate. Animals' transition to industrial development methods resulted in the concentration of large numbers of animals in small areas. Large dairy complexes were composed by animals not prepared for unusual keeping conditions. In this regard, we wanted to find out what are the protective reactions the calves' bodies kept in livestock complexes. The study of the protective reaction of calves' bodies, bacteriocidal and lysozyme blood activity showed that bactericidity amounted to $(\mathrm{mm}) 0,5 \pm 0.1$ in February, March - 7.9 $\pm 1,1$, April - 8.8 $\pm 1,3$, May - 8.6 \pm 0.5 , October - $8.5 \pm 0.08$, November - $8.4 \pm 0.14$ and December - 9.5 \pm 0.01 . Lysozyme activity, respectively: $9.1 \pm 2.8,8.5 \pm 0.8,8.5 \pm 0.1,8.5 \pm 0.6,9.6 \pm 0.2,9.2 \pm 0.18$, and $8.2 \pm 0.14$. The given data indicate that such protective body reactions as bacteriocidity and lysozyme activity of calves' blood are within the physiological norms.

\section{Conclusion}

To meet the growing needs of the country's population, livestock has been transferred to the rails of industrial development. In the Republic of Dagestan, dairy and fattening complexes of tied and loose housing systems have been built. One of the conditions for maintaining health and increasing the productivity of livestock is the creation of optimal keeping conditions. The results of the study of the livestock premises' microclimate showed: the temperature in the calf pan, the concentration of carbon dioxide and ammonia corresponded to zoohygienic standards; indicators of relative humidity and air velocity exceeded the permissible zoohygienic standards. Indicators of the physiological state of calves: body temperature, heart rate and respiratory rate corresponded to the norms of a healthy animal. Hematological and biochemical blood indicators of calves were within the physiological norm. Bacteriocidal and lysozyme properties of calves' blood show that the body's protective reactions are within the physiological norm.

\section{References}

1. L.V. Gornin, Public Administration Issues, 3, 65-85 (2018)

2. K.A. Abdulaev, A.Z. Magomedova, Proceedings of DSPU. Natural and Exact Sciences, 1, 113-120 (2007)

3. M.A. Mirzakarimova, Hygiene and sanitary, 6, 528-531 (2017)

4. N.P. Mishurov, Engineering and Technology in Animal Husbandry, 3 (31), 77-88 (2018)

5. D.M. Bekenov, V.G. Semenov, A.E. Chindaliyev, A. D. Baymukanov, S.D. Mongush, Bulletin of Tuva State University. Natural and Agricultural Sciences, 3 (62), 57-68 (2020) 
6. Yu.V. Mamaeva, V.A. Abushova, Engineering and Construction Bulletin of the Caspian Sea, 2 (32), 95-97 (2020)

7. A.N. Kartashova, I.V. Schebenok, Actual problems of intensive animal husbandry development, 23 (2), 199-206 (2020)

8. T.L. Mayorova, D.G. Musiev, R.M. Abduragimova, Sh.A. Gunashev, G.Kh. Azaev, G.A. Dzhabarova, South of Russia: ecology, development, 3, 193-201 (2016) 